\title{
Response Surfaces for Fresh and Hardened Properties of Concrete with E-Waste (HIPS)
}

\author{
K. Senthil Kumar and K. Baskar \\ Department of Civil Engineering, National Institute of Technology, Tiruchirappalli, Tamil Nadu 620015, India
}

Correspondence should be addressed to K. Senthil Kumar; senthilkumark13@yahoo.com

Received 17 July 2014; Accepted 10 September 2014; Published 25 September 2014

Academic Editor: Milva Pepi

Copyright (C) 2014 K. Senthil Kumar and K. Baskar. This is an open access article distributed under the Creative Commons Attribution License, which permits unrestricted use, distribution, and reproduction in any medium, provided the original work is properly cited.

\begin{abstract}
The fresh and hardened properties of concrete with E-waste plastic, that is, high impact polystyrene (HIPS), as a partial replacement for coarse aggregate were analyzed using response surface methodology (RSM). Face-centred central composite response surface design was used in this study. The statistical models were developed between the factors (HIPS and water cement ratio) and their response variables (slump, fresh density, dry density, compressive strength, spilt tensile strength, and flexural strength). The Design-Expert 9.0.3 software package was used to analyze the experimental values. The relationships were established and final mathematical models in terms of coded factors from predicted responses were developed. The effects of factors on properties for all variables were seen visually from the response surface and contour plot. Validation of experiments has shown that the experimental value closely agreed with the predicted value, which validates the calculated response surface models with desirability $=1$. The HIPS replacement influenced all the properties of concrete than water cement ratio. Even though all properties show the decline trend, the experimented values and predicted values give a hope that the E-waste plastic (HIPS) can be used as coarse aggregate up to certain percentage of replacement in concrete which successively reduces the hazardous solid waste problem and conserves the natural resources from exhaustion.
\end{abstract}

\section{Introduction}

Generation of solid waste and its safe disposal have become a challenging task for developing and developed countries. Among the solid waste, electronic waste (E-waste) shows an alarming growth. For the past few decades, the developed and developing countries totally ignored this waste. The major reasons are complexity of waste, lack of recycling infrastructure, recycling in informal sector, lack of awareness among people, and so forth. Now, the E-waste generation receives the attention of the developed countries but their way of recycling the E-waste is different; that is, they have started exporting this harm to developing countries as shown in Figure 1 $[1,2]$. E-waste comprises many toxic substances like mercury, lead, cadmium, brominated flame-retardants, beryllium, polyvinyl chloride, printed circuit boards, plastic casings, cathode ray tubes, batteries, and cable sheathing, and so forth, which are harmful to human health and environment if not handled properly [3-5]. In developing countries, after recovering the precious metals and useful materials from the E-waste in informal manner, the waste is being disposed in land, water body, or in open incineration. Most of the developing nations have framed the laws to restrict the import of E-waste and recycling in informal manner but the rules are in print without spirit.

E-waste disposals impact human health in two ways which include (a) food chain issues: contamination by toxic substances from disposal and primitive recycling processes that result in byproducts entering the food chain and thus transferring to humans and (b) direct impact on workers who labour in primitive recycling areas from their occupational exposure to toxic substances [6,7]. A joint study on electronic waste generation was carried out by the Manufacturer's Association of Information Technology (MAIT) of India and Gesellschaft für Technische Zusammenarbeit (GTZ) of Germany in India during 2007. The estimated generation of 


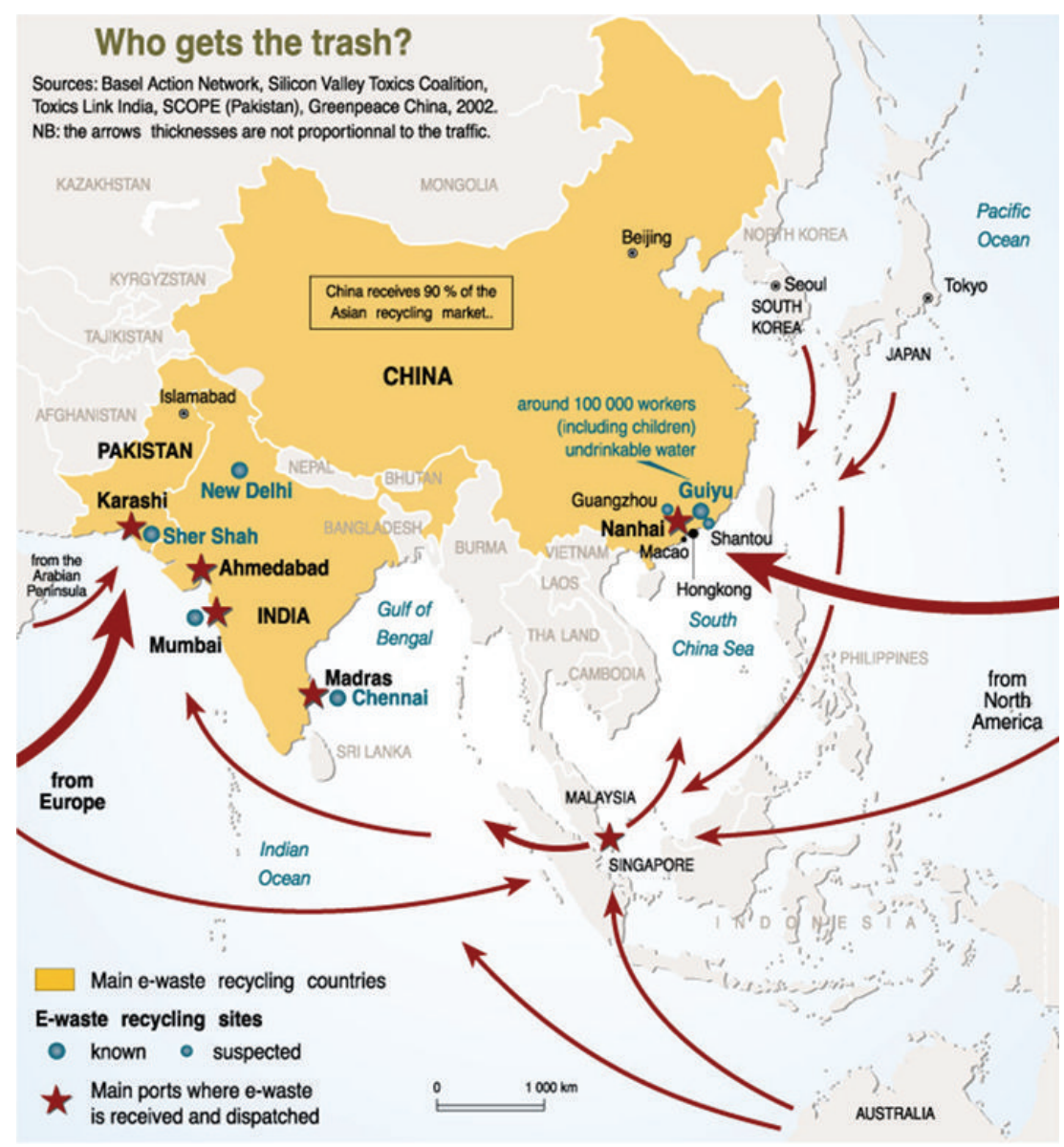

Figure 1: Asian E-waste traffic $[1,2]$.

electronic waste was approximately 400,000 tonnes of waste annually (from computers, mobile phones, and television sets only), which is expected to grow at a rate of $10-15 \%$ per year. The study also reveals that only about 19,000 tons of E-waste is recycled and large amounts of E-waste are refurbished and sold in the secondary market $[8,9]$.

Throughout the world, there has been a rapid increase in the utilization of concrete today, which results in increased consumption of natural aggregate. The developing countries are consuming more concrete to develop their infrastructure; this leads to the depletion of natural aggregates sources. In order to conserve the natural aggregate resources and to avoid environmental pollution, researchers have considered the different types of waste materials generated from different sources $[10,11]$ and adopted them to fine aggregate and coarse aggregate such as recycled aggregate [11-13], postconsumer plastics [14-16], and scrap tyres [17, 18]. Recently, researchers have started to minimize the E-waste impact on the environment by preserving the natural aggregate resource and by utilizing the E-waste as construction material as an alternative to natural aggregate.

In E-waste, researchers focused only on the usage of plastic and glass waste from electrical and electronic equipment to use as an aggregate in cement and concrete composites $[9,19-30]$.

\section{Materials and Methods}

In this experimental investigation, the recycled computer plastic waste from E-waste has been used as a partial substitute for coarse aggregate in concrete; that is, high impact polystyrene (HIPS) plastic from computers and its accessories are used in the concrete as a partial substitute for coarse aggregate in various volume percentages such as $10 \%, 20 \%, 30 \%$, 40\%, and 50\%. Ordinary Portland cement (OPC 53 Grade) with specific gravity of 3.13 was used in all concrete mixtures meeting the specifications of IS 122691987 [31]. The broken granite with a maximum size of $12.5 \mathrm{~mm}$, specific gravity of 2.79 , and density of $1624.22 \mathrm{~kg} / \mathrm{m}^{3}$ has been taken as a coarse aggregate. River sand with a maximum size of $4.75 \mathrm{~mm}$, specific gravity of 2.65 , and density of $1656.09 \mathrm{~kg} / \mathrm{m}^{3}$ has been taken as fine aggregate. HIPS aggregate with a size varying from 6 to $12 \mathrm{~mm}$, specific gravity of 1.29 , and density of $595.30 \mathrm{~kg} / \mathrm{m}^{3}$ has been used to meet the specifications of IS 2386-1963 (Parts I-IV) [32]. The HIPS aggregate has flaky shape, smooth texture, and uniform black colour as shown in Figure 2. The concrete mix of three different grades of concrete (M20, M25, and M30) with three different water cement ratios $(0.45,0.49$, and 0.53$)$ was designed on the basis of IS 10262-2009 as shown in Table 1 [33]. Potable water available in college campus was used in all 
TABLE 1: Concrete mix proportions (IS 10262:2009).

\begin{tabular}{|c|c|c|c|c|c|c|}
\hline \multirow{2}{*}{ Concrete grade } & \multirow{2}{*}{$W / C$ ratio } & \multirow{2}{*}{ HIPS content $(\%)^{*}$} & \multicolumn{4}{|c|}{ Mix proportions $\left(\mathrm{kg} / \mathrm{m}^{3}\right)$} \\
\hline & & & Cement & Fine aggregate & Coarse aggregate & HIPS aggregate \\
\hline \multirow{6}{*}{ M20 } & \multirow{6}{*}{0.53} & Control batch & \multirow{6}{*}{340.00} & \multirow{6}{*}{799.23} & 1147.81 & 0.00 \\
\hline & & 10 & & & 1033.02 & 53.07 \\
\hline & & 20 & & & 919.04 & 106.14 \\
\hline & & 30 & & & 803.66 & 159.12 \\
\hline & & 40 & & & 688.28 & 212.46 \\
\hline & & 50 & & & 572.91 & 264.89 \\
\hline \multirow{6}{*}{ M25 } & \multirow{6}{*}{0.49} & Control batch & \multirow{6}{*}{367.34} & \multirow{6}{*}{789.14} & 1133.32 & 0.00 \\
\hline & & 10 & & & 1019.98 & 52.40 \\
\hline & & 20 & & & 907.44 & 104.80 \\
\hline & & 30 & & & 793.52 & 157.11 \\
\hline & & 40 & & & 679.59 & 209.78 \\
\hline & & 50 & & & 565.67 & 261.55 \\
\hline \multirow{6}{*}{ M30 } & \multirow{6}{*}{0.45} & Control batch & \multirow{6}{*}{400.00} & \multirow{6}{*}{777.93} & 1117.22 & 0.00 \\
\hline & & 10 & & & 1005.49 & 51.65 \\
\hline & & 20 & & & 894.55 & 103.31 \\
\hline & & 30 & & & 782.24 & 154.87 \\
\hline & & 40 & & & 669.94 & 206.80 \\
\hline & & 50 & & & 557.64 & 257.83 \\
\hline
\end{tabular}

${ }^{*}$ Percentage replacement by volume.

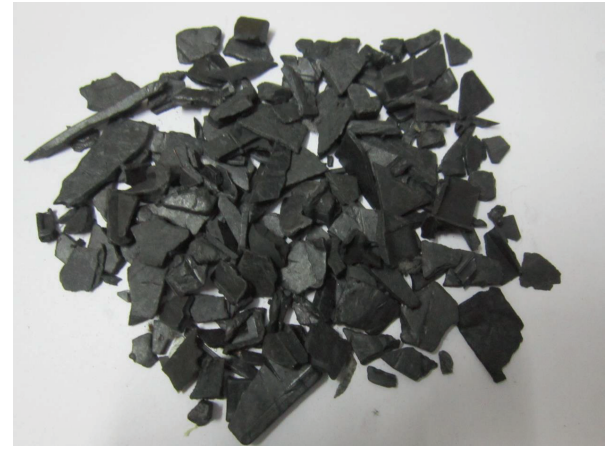

FIgURE 2: E-waste plastic (HIPS as aggregate).

concrete mixes on the basis of IS 456-2000 [34]. The fresh and hardened properties of concrete tests were performed in accordance with the IS 516-1959 [35] and IS 1199-1959 [36].

\section{Experimental Design}

According to Montgomery, response surface methodology (RSM) is a collection of mathematical and statistical techniques used for modeling and analyzing of problems in which a response of interest is influenced by several variables and the objective is to optimize this response [37]. In this study, the fresh and hardened properties of concrete were analyzed and relationships were developed based on RSM. The response surface design used in this study is face-centred central composite response surface design. A face-centred central composite response surface design with $\alpha=1$ and full quadratic model for each response was used. The statistical
TABLE 2: Factors and factor levels adopted for RSM.

\begin{tabular}{lcccc}
\hline & & \multicolumn{3}{c}{ Factor levels of code } \\
Factor & Code & Low level & Intermediate level & High level \\
& & -1 & 0 & 1 \\
\hline HIPS (Vol \%) & $A$ & 10 & 30 & 50 \\
$W / C$ ratio & $B$ & 0.45 & 0.49 & 0.53 \\
\hline
\end{tabular}

software “Design-Expert version 9.0.3," Stat-Ease, Inc., is used to analyze the experimental design. The volume percentage of HIPS (Vol\%) is coded as $A$ and water cement ratio (W/C ratio) is coded as $B$; both were selected as the factors and studied at different 3 levels. The factors and factor levels are shown in Table 2.

Table 3 presents the experimental runs, their factor combinations, the translation of the coded levels to the actual experimental units, and space types used in this study. Fresh properties such as slump, fresh density, and hardened properties such as dry density at 28 days and compressive strength, spilt tensile strength, and flexural strength at 7 and 28 days were taken as the response variables. Equation (1) shows the full quadratic model in terms of coded factors:

$$
Y=\beta_{0}+\beta_{1} A+\beta_{2} B+\beta_{12} A B+\beta_{11} A^{2}+\beta_{22} B^{2},
$$

where $Y$ is predicted response; $\beta_{0}$ is intercept; $\beta_{1}, \beta_{2}$ are linear effect coefficients; $\beta_{11}, \beta_{22}$ are quadratic effect coefficients; $\beta_{12}$ is interaction effect coefficient.

\section{Results and Discussion}

Using Design-Expert software version 9.0.3, the experimentally obtained fresh and hardened properties of concrete 
TABLE 3: Factor combinations as per the face-centred central composite response surface design.

\begin{tabular}{|c|c|c|c|c|c|}
\hline \multirow{2}{*}{ Run } & \multicolumn{2}{|c|}{ Coded factor levels } & \multicolumn{2}{|c|}{ Actual factors } & \multirow{2}{*}{ Space type } \\
\hline & $A$ & $B$ & HIPS (Vol \%) & $W / C$ ratio & \\
\hline 1 & -1 & -1 & 10 & 0.45 & Factorial \\
\hline 2 & -1 & 0 & 10 & 0.49 & Axial \\
\hline 3 & -1 & 1 & 10 & 0.53 & Factorial \\
\hline 4 & 0 & -1 & 30 & 0.45 & Axial \\
\hline 5 & 0 & 0 & 30 & 0.49 & Center \\
\hline 6 & 0 & 1 & 30 & 0.53 & Axial \\
\hline 7 & 1 & -1 & 50 & 0.45 & Factorial \\
\hline 8 & 1 & 0 & 50 & 0.49 & Axial \\
\hline 9 & 1 & 1 & 50 & 0.53 & Factorial \\
\hline 10 & 0 & 0 & 30 & 0.49 & Center \\
\hline 11 & 0 & 0 & 30 & 0.49 & Center \\
\hline 12 & 0 & 0 & 30 & 0.49 & Center \\
\hline 13 & 0 & 0 & 30 & 0.49 & Center \\
\hline
\end{tabular}

TABLE 4: Actual and predicted values of slump $(\mathrm{mm})$, fresh density $\left(\mathrm{kg} / \mathrm{m}^{3}\right)$, and dry density $\left(\mathrm{kg} / \mathrm{m}^{3}\right)$.

\begin{tabular}{|c|c|c|c|c|c|c|c|c|}
\hline \multirow{2}{*}{ Run } & \multirow{2}{*}{$\begin{array}{c}A \\
\text { HIPS (Vol \%) }\end{array}$} & \multirow{2}{*}{$\begin{array}{c}B \\
W / C \text { ratio }\end{array}$} & \multicolumn{2}{|c|}{ Slump (mm) } & \multicolumn{2}{|c|}{ Fresh density $\left(\mathrm{kg} / \mathrm{m}^{3}\right)$} & \multicolumn{2}{|c|}{ Dry density $\left(\mathrm{kg} / \mathrm{m}^{3}\right)$} \\
\hline & & & Actual value & Predicted value & Actual value & Predicted value & Actual value & Predicted value \\
\hline 1 & -1 & -1 & 24.00 & 23.07 & 2629.14 & 2638.64 & 2489.98 & 2484.52 \\
\hline 2 & -1 & 0 & 24.33 & 25.53 & 2598.52 & 2604.30 & 2467.85 & 2472.64 \\
\hline 3 & -1 & 1 & 25.67 & 25.40 & 2571.85 & 2556.58 & 2461.63 & 2462.30 \\
\hline 4 & 0 & -1 & 11.00 & 12.64 & 2495.80 & 2468.72 & 2278.02 & 2277.64 \\
\hline 5 & 0 & 0 & 15.00 & 14.61 & 2428.15 & 2429.07 & 2232.10 & 2234.70 \\
\hline 6 & 0 & 1 & 13.67 & 13.98 & 2353.58 & 2376.05 & 2205.93 & 2193.30 \\
\hline 7 & 1 & -1 & 10.33 & 9.62 & 2287.41 & 2304.99 & 2160.49 & 2166.33 \\
\hline 8 & 1 & 0 & 10.33 & 11.08 & 2270.42 & 2260.03 & 2110.12 & 2092.32 \\
\hline 9 & 1 & 1 & 10.00 & 9.96 & 2208.89 & 2201.70 & 2007.90 & 2019.86 \\
\hline 10 & 0 & 0 & 15.00 & 14.61 & 2428.15 & 2429.07 & 2232.10 & 2234.70 \\
\hline 11 & 0 & 0 & 15.00 & 14.61 & 2428.15 & 2429.07 & 2232.10 & 2234.70 \\
\hline 12 & 0 & 0 & 15.00 & 14.61 & 2428.15 & 2429.07 & 2232.10 & 2234.70 \\
\hline 13 & 0 & 0 & 15.00 & 14.61 & 2428.15 & 2429.07 & 2231.10 & 2234.70 \\
\hline
\end{tabular}

with HIPS were analyzed and the design matrix of the variables in the coded units are shown in Tables 4-6 along with the actual values (experimental values) and predicted values of responses. The predicted values of responses were obtained using the Design-Expert software; for each factor, full quadratic model (second order polynomial) was employed and the coefficients of the parameters are given by the regression equation.

The regression equation gave the predicted values and the final mathematical models in terms of coded factors were arrived. Analyses of variance (ANOVA) of the predicted response surface models for all variables are presented in Tables 7-15. In this study, the $P$ value approach is employed for hypothesis testing; that is, "Prob $>F$ " less than 0.05 indicates that model terms are statistically significant.

4.1. Response Surface for Fresh Properties. The experimental values show that the slump and fresh density of concrete decrease with the increase of HIPS. The experimental values were used to study the effect of $W / C$ ratio and HIPS (Vol\%) in fresh concrete properties using RSM. Table 4 presents the actual and predicted values of slump ( $\mathrm{mm})$ and fresh density $\left(\mathrm{kg} / \mathrm{m}^{3}\right)$ of fresh concrete with HIPS. Tables 7 and 8 present the results of the ANOVA for slump and fresh density response surface quadratic model obtained.

Table 7 shows that the HIPS\% effect $(P<0.0001)$ and the quadratic HIPS\% effect $(P=0.0005)$ were statistically significant at the stipulated level of $5 \%$. The $W / C$ ratio effect $(P=0.1463)$, quadratic $W / C$ ratio effect, and the effect of interaction of HIPS\% and $W / C$ ratio $(P=0.3514)$ were statistically not significant at the stipulated level of $5 \%$. Equation (2) gives the final mathematical models in terms of coded factors:

$$
\begin{aligned}
& \text { Slump }(\mathrm{mm}) \\
& \quad=14.61-7.22 A+0.67 B-0.5 A B+3.70 A^{2}-1.3 B^{2} .
\end{aligned}
$$


TABLE 5: Actual and predicted values of compressive strength (MPa), split tensile strength (MPa), and flexural strength (MPa) at 7 days.

\begin{tabular}{|c|c|c|c|c|c|c|c|c|}
\hline \multirow{2}{*}{ Run } & \multirow{2}{*}{$\begin{array}{c}A \\
\text { HIPS (Vol \%) }\end{array}$} & \multirow{2}{*}{$\begin{array}{c}B \\
W / C \text { ratio }\end{array}$} & \multicolumn{2}{|c|}{ Compressive strength (MPa) } & \multicolumn{2}{|c|}{ Split tensile strength $(\mathrm{MPa})$} & \multicolumn{2}{|c|}{ Flexural strength $(\mathrm{MPa})$} \\
\hline & & & Actual value & Predicted value & Actual value & Predicted value & Actual value & Predicted value \\
\hline 1 & -1 & -1 & 25.00 & 25.21 & 2.37 & 2.35 & 6.07 & 6.12 \\
\hline 2 & -1 & 0 & 22.91 & 23.11 & 2.18 & 2.19 & 5.33 & 5.27 \\
\hline 3 & -1 & 1 & 19.14 & 18.73 & 1.96 & 1.97 & 4.47 & 4.48 \\
\hline 4 & 0 & -1 & 23.61 & 22.92 & 2.02 & 2.06 & 5.33 & 5.27 \\
\hline 5 & 0 & 0 & 20.94 & 20.97 & 1.91 & 1.91 & 4.53 & 4.54 \\
\hline 6 & 0 & 1 & 16.19 & 16.75 & 1.71 & 1.69 & 3.87 & 3.87 \\
\hline 7 & 1 & -1 & 16.09 & 16.57 & 1.65 & 1.63 & 4.20 & 4.21 \\
\hline 8 & 1 & 0 & 15.11 & 14.78 & 1.49 & 1.49 & 3.60 & 3.60 \\
\hline 9 & 1 & 1 & 10.86 & 10.71 & 1.27 & 1.28 & 3.07 & 3.05 \\
\hline 10 & 0 & 0 & 20.94 & 20.97 & 1.91 & 1.91 & 4.53 & 4.54 \\
\hline 11 & 0 & 0 & 20.94 & 20.97 & 1.91 & 1.91 & 4.53 & 4.54 \\
\hline 12 & 0 & 0 & 20.94 & 20.97 & 1.91 & 1.91 & 4.53 & 4.54 \\
\hline 13 & 0 & 0 & 20.94 & 20.97 & 1.91 & 1.91 & 4.53 & 4.54 \\
\hline
\end{tabular}

TABLE 6: Actual and predicted values of compressive strength (MPa), split tensile strength (MPa), and flexural strength (MPa) at 28 days.

\begin{tabular}{|c|c|c|c|c|c|c|c|c|}
\hline \multirow{2}{*}{ Run } & \multirow{2}{*}{$\begin{array}{c}A \\
\text { HIPS (Vol \%) }\end{array}$} & \multirow{2}{*}{$\begin{array}{c}B \\
W / C \text { ratio }\end{array}$} & \multicolumn{2}{|c|}{ Compressive strength $(\mathrm{MPa})$} & \multicolumn{2}{|c|}{ Split tensile strength $(\mathrm{MPa})$} & \multicolumn{2}{|c|}{ Flexural strength $(\mathrm{MPa})$} \\
\hline & & & Actual value & Predicted value & Actual value & Predicted value & Actual value & Predicted value \\
\hline 1 & -1 & -1 & 43.54 & 45.15 & 3.07 & 3.08 & 6.87 & 6.89 \\
\hline 2 & -1 & 0 & 37.07 & 35.95 & 2.90 & 2.91 & 6.33 & 6.32 \\
\hline 3 & -1 & 1 & 26.05 & 25.55 & 2.78 & 2.76 & 5.47 & 5.46 \\
\hline 4 & 0 & -1 & 39.60 & 36.16 & 2.47 & 2.49 & 5.67 & 5.65 \\
\hline 5 & 0 & 0 & 27.76 & 28.29 & 2.31 & 2.29 & 5.20 & 5.19 \\
\hline 6 & 0 & 1 & 18.46 & 19.23 & 2.05 & 2.12 & 4.40 & 4.45 \\
\hline 7 & 1 & -1 & 24.32 & 26.15 & 1.92 & 1.89 & 4.87 & 4.86 \\
\hline 8 & 1 & 0 & 21.18 & 19.62 & 1.59 & 1.67 & 4.47 & 4.52 \\
\hline 9 & 1 & 1 & 12.17 & 11.89 & 1.53 & 1.48 & 3.93 & 3.89 \\
\hline 10 & 0 & 0 & 27.76 & 28.29 & 2.31 & 2.29 & 5.20 & 5.19 \\
\hline 11 & 0 & 0 & 27.76 & 28.29 & 2.31 & 2.29 & 5.20 & 5.19 \\
\hline 12 & 0 & 0 & 27.76 & 28.29 & 2.31 & 2.29 & 5.20 & 5.19 \\
\hline 13 & 0 & 0 & 27.76 & 28.29 & 2.31 & 2.29 & 5.20 & 5.19 \\
\hline
\end{tabular}

TABLE 7: Analysis of variance for slump ( $\mathrm{mm})$ response surface quadratic model.

\begin{tabular}{|c|c|c|c|c|c|}
\hline Source & Sum of squares & Degrees of freedom & Mean square & $F$ value & $P$ value \\
\hline Model & 354.56 & 5 & 70.91 & 70.65 & $<0.0001$ \\
\hline A-HIPS ( $\mathrm{Vol} \%)$ & 313.06 & 1 & 313.06 & 311.91 & $<0.0001$ \\
\hline$B$-W/C ratio & 2.68 & 1 & 2.68 & 2.67 & 0.1463 \\
\hline$A B$ & 1.00 & 1 & 1.00 & 1.00 & 0.3514 \\
\hline$A^{2}$ & 37.78 & 1 & 37.78 & 37.64 & 0.0005 \\
\hline$B^{2}$ & 4.64 & 1 & 4.64 & 4.62 & 0.0686 \\
\hline Residual & 7.03 & 7 & 1.00 & & \\
\hline Lack of fit & 7.03 & 3 & 2.34 & & \\
\hline Pure error & 0.00 & 4 & 0.00 & & \\
\hline Total & 361.59 & 12 & & & \\
\hline
\end{tabular}


TABLE 8: Analysis of variance for fresh density $\left(\mathrm{kg} / \mathrm{m}^{3}\right)$ response surface quadratic model.

\begin{tabular}{|c|c|c|c|c|c|}
\hline Source & Sum of squares & Degrees of freedom & Mean square & $F$ value & $P$ value \\
\hline Model & 190900.00 & 5 & 38179.30 & 129.25 & $<0.0001$ \\
\hline$A$-HIPS (Vol \%) & 177800.00 & 1 & 177800 & 601.85 & $<0.0001$ \\
\hline$B-W / C$ ratio & 12883.45 & 1 & 12883.45 & 43.62 & 0.0003 \\
\hline$A B$ & 112.68 & 1 & 112.68 & 0.38 & 0.5564 \\
\hline$A^{2}$ & 26.40 & 1 & 26.40 & 0.089 & 0.7737 \\
\hline$B^{2}$ & 123.55 & 1 & 123.55 & 0.42 & 0.5384 \\
\hline Residual & 2067.69 & 7 & 295.38 & & \\
\hline Lack of fit & 2067.69 & 3 & 689.23 & & \\
\hline Pure error & 0.000 & 4 & 0.000 & & \\
\hline Total & 193000 & 12 & & & \\
\hline
\end{tabular}

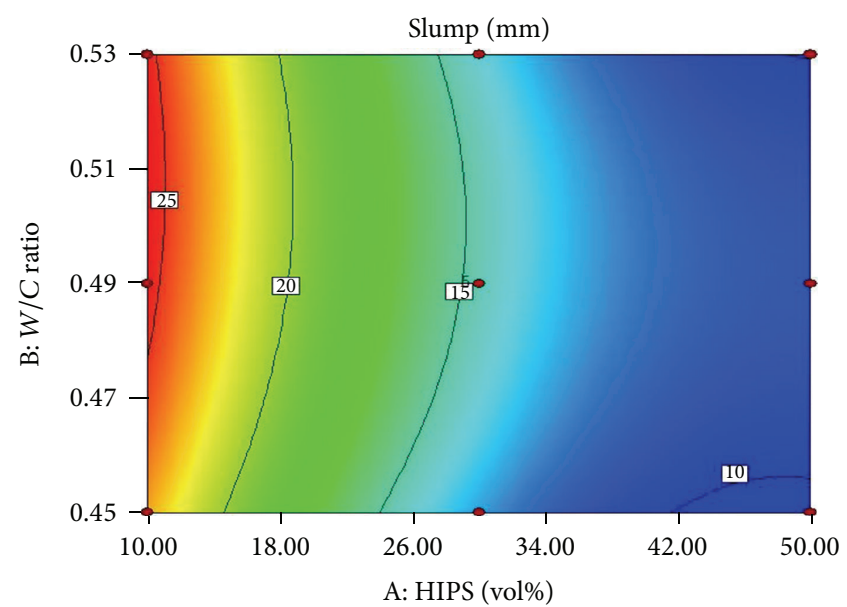

(a)

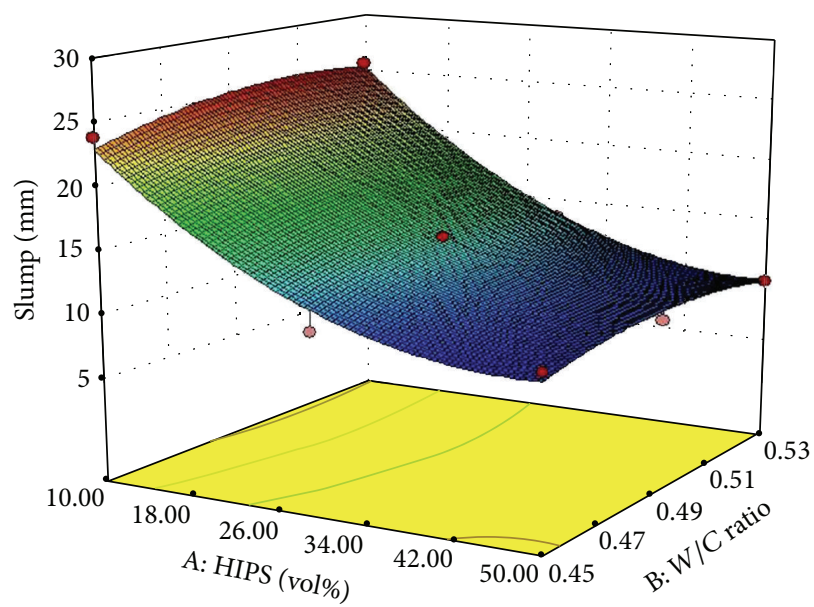

(b)

Figure 3: Contour plot and response surface of a slump.

The effect of each variable on this property can be seen as contour plot and response, as shown in Figure 3.

Table 8 shows the analysis of variance for fresh density $\left(\mathrm{kg} / \mathrm{m}^{3}\right)$ response surface quadratic model. In that, the HIPS\% effect $(P<0.0001)$ and the $W / C$ ratio effect $(P=$ 0.0003 ) were statistically significant at the stipulated level of $5 \%$. The quadratic $W / C$ ratio $(P=0.5384)$ and $\mathrm{HIPS} \%$ effect $(P=0.7737)$ as well as the effect of interaction of HIPS\% and $W / C$ ratio $(P=0.5564)$ was statistically not significant at the stipulated level of $5 \%$. Equation (3) is the final fitting equation in terms of coded factors:

$$
\begin{aligned}
& \text { Fresh density }\left(\mathrm{kg} / \mathrm{m}^{3}\right) \\
& \qquad \begin{aligned}
= & 2429.07-172.13 A-46.34 B-5.31 A B \\
& +3.09 A^{2}-6.69 B^{2} .
\end{aligned}
\end{aligned}
$$

The fresh density decreases with the $W / C$ ratio and decreases when the HIPS content increases.

The effect of each variable on this property is plotted as response and contour plot, as shown in Figure 4.
4.2. Response Surface for Hardened Properties. Table 4 presents actual and predicted values of dry density $\left(\mathrm{kg} / \mathrm{m}^{3}\right)$ and Table 9 presents the results of the ANOVA for the dry density $\left(\mathrm{kg} / \mathrm{m}^{3}\right)$. Table 8 shows that the HIPS\% effect $(P<0.0001)$, the quadratic HIPS\% effect $(P=0.0001)$, the $W / C$ ratio effect $(P<0.0001)$, and the effect of interaction of HIPS\% and $W / C$ ratio $(P=0.0005)$ were statistically significant at the stipulated level of $5 \%$. The quadratic $W / C$ ratio effect $(P=0.9045)$ was not reached the statistically significant at the stipulated level of 5\%. Equation (4) is the final mathematical equation in terms of coded factors:

$$
\begin{aligned}
\text { Dry density }\left(\mathrm{kg} / \mathrm{m}^{3}\right) \\
=2234.70-190.16 A-42.17 B-31.06 A B \\
\quad+47.78 A^{2}+0.77 B^{2} .
\end{aligned}
$$

The effect of each variable on this property was plotted as response and contour plot, as shown in Figure 5. It can be seen from Figure 5 that the dry density decreases with the increase of HIPS, since the density of HIPS is less when compared to 


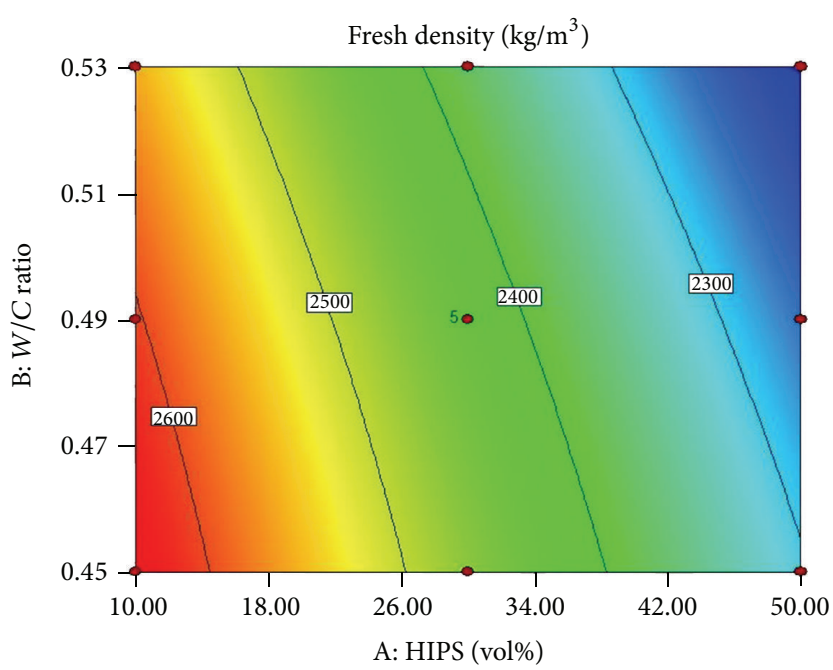

(a)

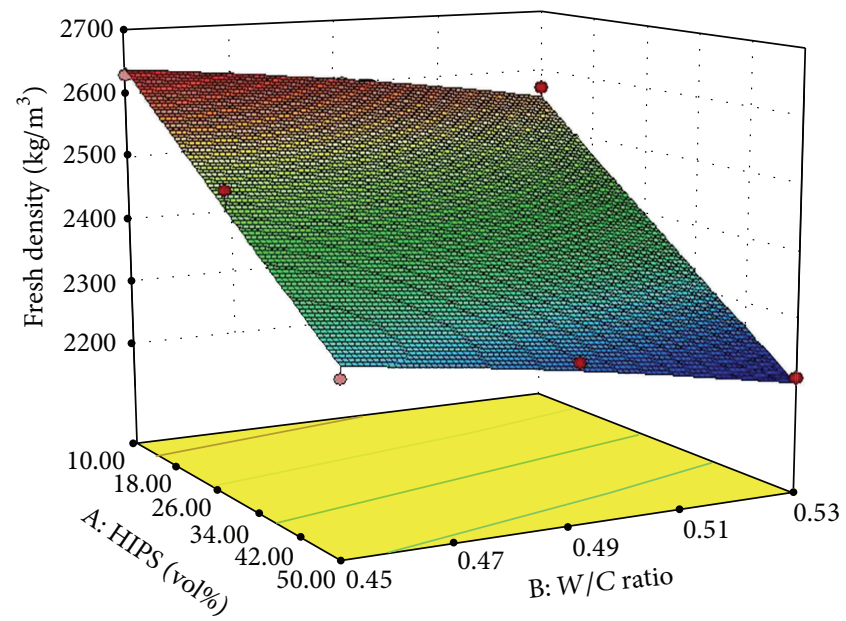

(b)

FIGURE 4: Contour plot and response surface of a fresh density.

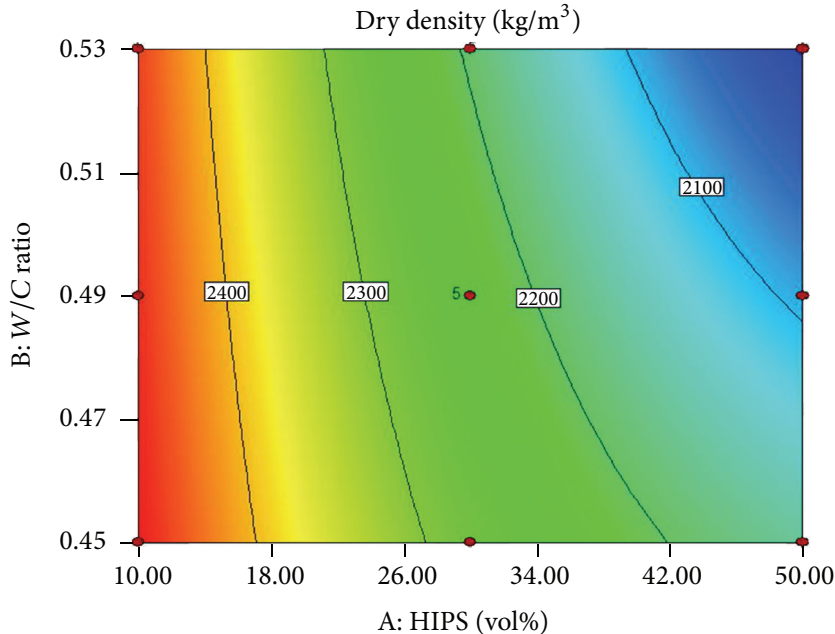

(a)

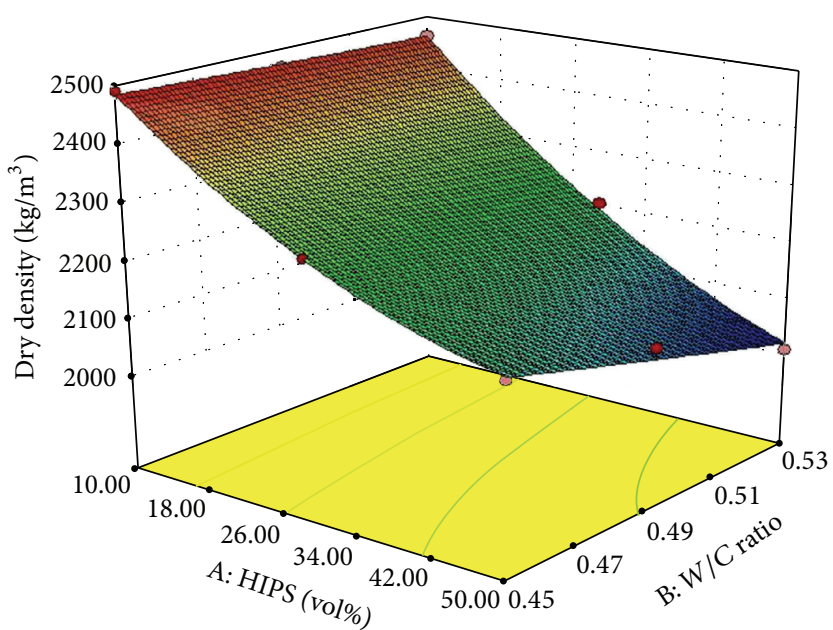

(b)

FIGURE 5: Contour plot and response surface of a dry density.

TABLE 9: Analysis of variance for dry density $\left(\mathrm{kg} / \mathrm{m}^{3}\right)$ response surface quadratic model.

\begin{tabular}{lcccc}
\hline Source & Sum of squares & Degrees of freedom & Mean square & $F$ value \\
\hline Model & 239000 & 5 & 47791.78 & 451.76 \\
$A$-HIPS (Vol \%) & 217000 & 1 & 217000 & 2050.85 \\
$B$-W/C ratio & 10670.70 & 1 & 10670.70 & 100.87 \\
$A B$ & 3858.89 & 1 & 3858.89 & 36.48 \\
$A^{2}$ & 6305.28 & 1 & 6305.28 & 59.60 \\
$B^{2}$ & 1.64 & 1 & 1.64 & 0.015 \\
Residual & 740.54 & 7 & 105.79 & 0.0001 \\
Lack of fit & 740.54 & 3 & 246.85 & 0.9045 \\
Pure error & 0.000 & 4 & 0.000 & \\
\hline Total & 239700 & 12 & & \\
\hline
\end{tabular}


TABLE 10: Analysis of variance for 7-day compressive strength (MPa) response surface quadratic model.

\begin{tabular}{|c|c|c|c|c|c|}
\hline Source & Sum of squares & Degrees of freedom & Mean square & $F$ value & $P$ value \\
\hline Model & 184.36 & 5 & 36.87 & 183.13 & $<0.0001$ \\
\hline A-HIPS (Vol \%) & 104.08 & 1 & 104.08 & 516.93 & $<0.0001$ \\
\hline$B-W / C$ ratio & 57.10 & 1 & 57.10 & 283.60 & $<0.0001$ \\
\hline$A B$ & 0.099 & 1 & 0.099 & 0.49 & 0.5053 \\
\hline$A^{2}$ & 11.33 & 1 & 11.33 & 56.27 & 0.0001 \\
\hline$B^{2}$ & 3.56 & 1 & 3.56 & 17.68 & 0.0040 \\
\hline Residual & 1.41 & 7 & 0.20 & & \\
\hline Lack of fit & 1.41 & 3 & 0.47 & & \\
\hline Pure error & 0.000 & 4 & 0.000 & & \\
\hline Total & 185.77 & 12 & & & \\
\hline
\end{tabular}

TABLE 11: Analysis of variance for 28-day compressive strength (MPa) response surface quadratic model.

\begin{tabular}{|c|c|c|c|c|c|}
\hline Source & Sum of squares & Degrees of freedom & Mean square & $F$ value & $P$ value \\
\hline Model & 839.64 & 5 & 167.93 & 49.36 & $<0.0001$ \\
\hline A-HIPS (Vol \%) & 400.00 & 1 & 400.00 & 117.57 & $<0.0001$ \\
\hline$B$-W/C ratio & 429.77 & 1 & 429.77 & 126.32 & $<0.0001$ \\
\hline$A B$ & 7.13 & 1 & 7.13 & 2.10 & 0.1910 \\
\hline$A^{2}$ & 0.71 & 1 & 0.71 & 0.21 & 0.6625 \\
\hline$B^{2}$ & 1.00 & 1 & 1.00 & 0.29 & 0.6051 \\
\hline Residual & 23.81 & 7 & 3.40 & & \\
\hline Lack of fit & 23.81 & 3 & 7.94 & & \\
\hline Pure error & 0.000 & 4 & 0.000 & & \\
\hline Total & 863.45 & 12 & & & \\
\hline
\end{tabular}

natural coarse aggregate. This type of concrete can be used in situation where mass reduction is required.

Tables 5 and 6 present the actual and predicted values of 7-day and 28-day compressive strength of concrete cube specimens of size $150 \mathrm{~mm}$. Tables 10 and 11 present the results of the variance analysis for the 7-day and 28-day compressive strength using the response surface model. The compressive strength decreases with the increase of HIPS; for all W/C ratios, since the shape of HIPS is flaky and smooth in texture, there is lack of bond between the HIPS and mortar.

Table 10 shows that the linear and quadratic $W / C$ ratio effects $(P<0.0001$ and 0.0040 , resp.) are statistically significant at the stipulated level of $5 \%$. The linear and quadratic HIPS\% effects $(P<0.0001$ and 0.001 , resp.) are statistically significant at the stipulated level of $5 \%$. Equation (5) is the final fitting equation:

7 day Compressive strength $(\mathrm{MPa})$

$$
=20.97-4.16 A-3.08 B+0.16 A B-2.03 A^{2}-1.14 B^{2} .
$$

Table 11 shows that only the linear HIPS\% and $W / C$ ratio effects $(P<0.0001$ and $P<0.0001$, resp. $)$ are statistically significant at the stipulated level of $5 \%$. Equation (6) is the final fitting equation:

28 day Compressive strength $(\mathrm{MPa})$

$$
=28.29-8.17 A-8.46 B+1.34 A B-0.51 A^{2}-0.6 B^{2} .
$$

The effect of each variable on 7-day and 28-day compressive strength is plotted as response and contour plot, as shown in Figures 6 and 7.

Tables 5 and 6 show the actual and predicted values of 7 -day and 28-day spilt tensile strength of concrete cylinder specimens of size $150 \times 300 \mathrm{~mm}$.

Table 12 shows that only the linear HIPS\% and $W / C$ ratio effects $(P<0.0001$ and $P<0.0001$, resp. $)$ are statistically significant at the stipulated level of $5 \%$. Equation (7) is the final fitting equation:

7 day Spilt tensile strength $(\mathrm{MPa})$

$$
\begin{aligned}
= & 1.91-0.35 A-0.18 B+0.0075 A B-0.064 A^{2} \\
& -0.034 B^{2} .
\end{aligned}
$$

Table 13 shows that only the linear HIPS\% and $W / C$ ratio effects $(P<0.0001$ and $P<0.0001$, resp. $)$ are statistically significant at the stipulated level of $5 \%$. Equation (8) is the final fitting equation:

28 day Spilt tensile strength $(\mathrm{MPa})$

$$
=2.29-0.62 A-0.18 B-0.025 A B-0.022 A^{2}+0.013 B^{2} .
$$

The effect of each variable on 7-day and 28-day spilt tensile strength is plotted as response and contour plot, as shown in Figures 8 and 9. 


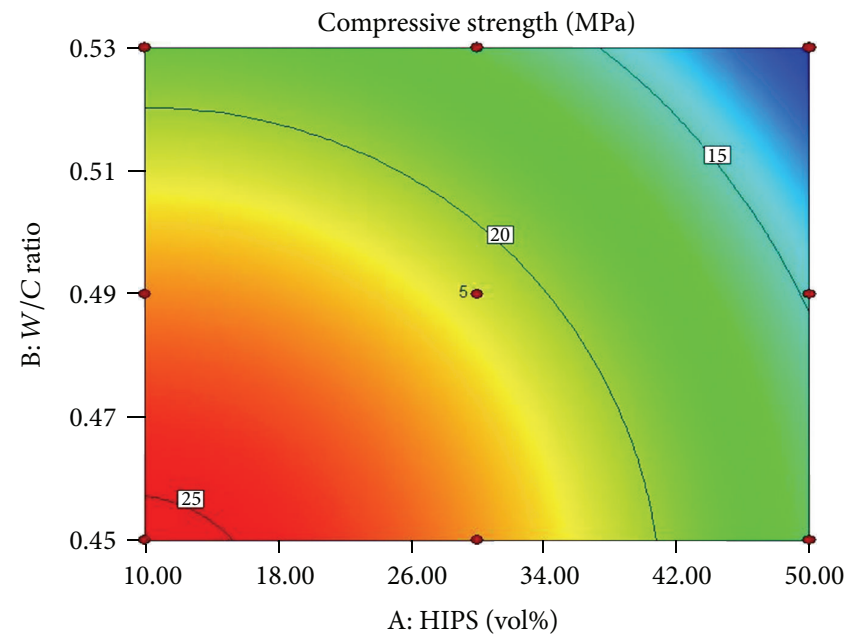

(a)

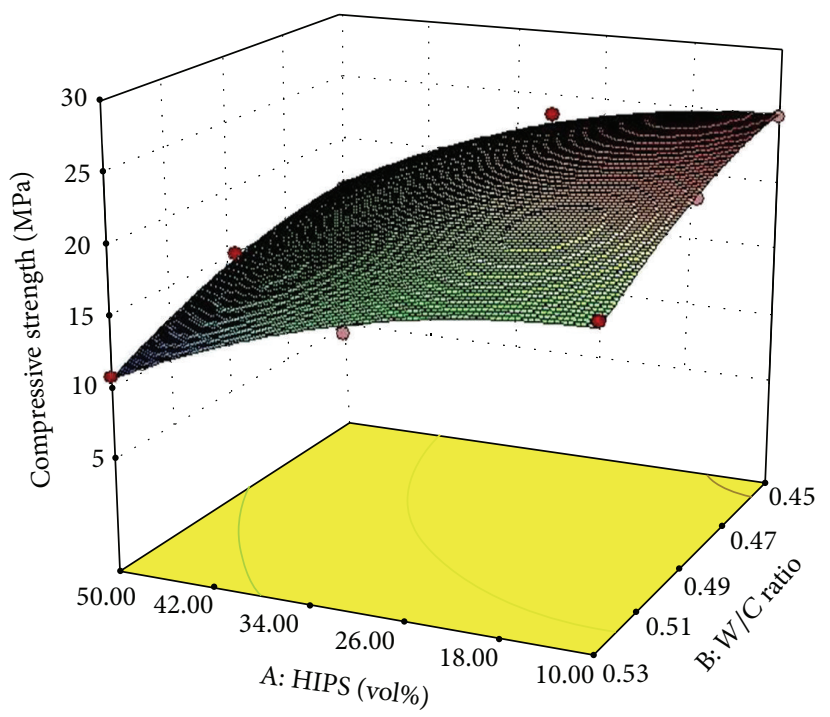

(b)

FIGURE 6: Contour plot and response surface of a 7-day compressive strength.

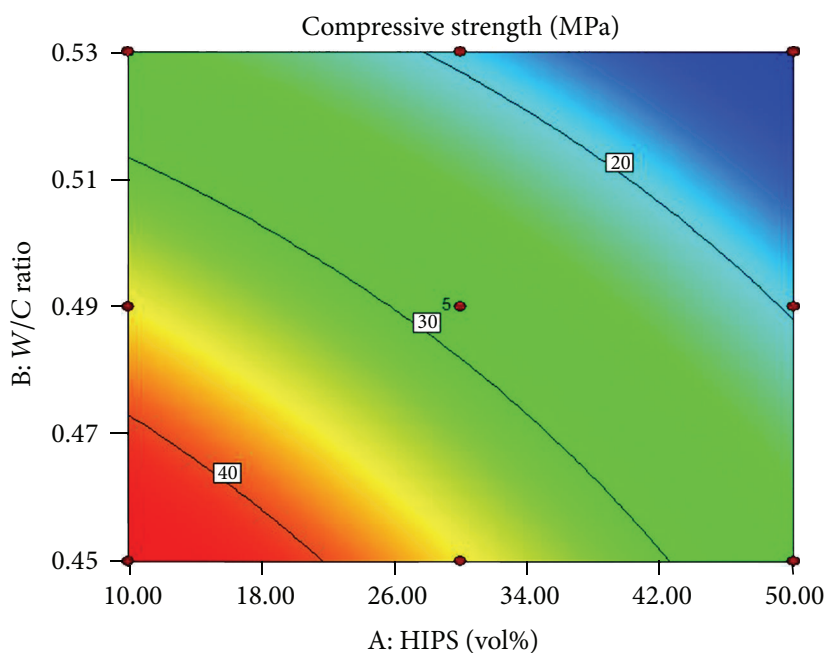

(a)

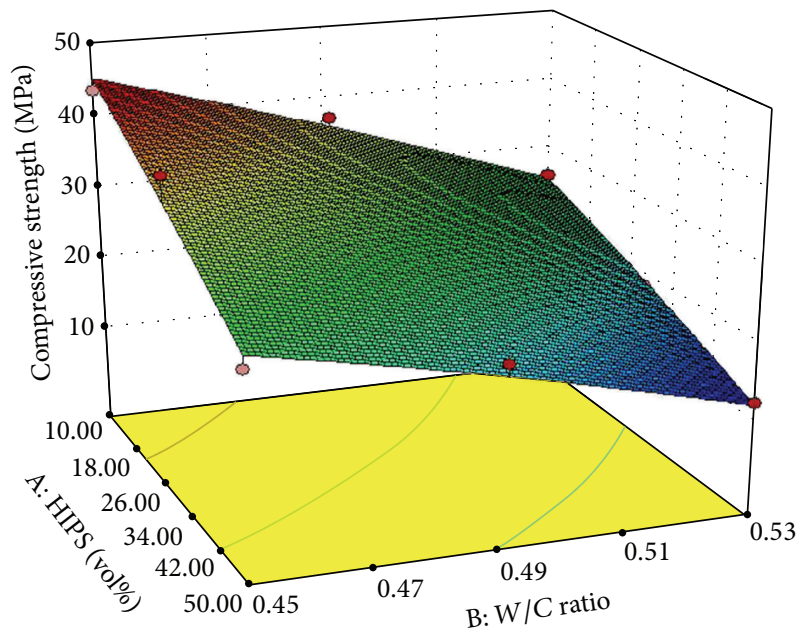

(b)

FIGURE 7: Contour plot and response surface of a 28-day compressive strength.

TABLE 12: Analysis of variance for 7-day split tensile strength (MPa) response surface quadratic model.

\begin{tabular}{|c|c|c|c|c|c|}
\hline Source & Sum of squares & Degrees of freedom & Mean square & $F$ value & $P$ value \\
\hline Model & 0.96 & 5 & 0.19 & 474.17 & $<0.0001$ \\
\hline A-HIPS (Vol \%) & 0.73 & 1 & 0.73 & 1816.44 & $<0.0001$ \\
\hline$B-W / C$ ratio & 0.20 & 1 & 0.20 & 498.39 & $<0.0001$ \\
\hline$A B$ & 0.000225 & 1 & 0.0002250 & 0.56 & 0.4801 \\
\hline$A^{2}$ & 0.011 & 1 & 0.011 & 28.08 & 0.0011 \\
\hline$B^{2}$ & 0.003219 & 1 & 0.003219 & 7.95 & 0.0258 \\
\hline Residual & 0.002832 & 7 & 0.0004046 & & \\
\hline Lack of fit & 0.002832 & 3 & 0.0009442 & & \\
\hline Pure error & 0.000 & 4 & 0.000 & & \\
\hline Total & 0.96 & 12 & & & \\
\hline
\end{tabular}


TABLE 13: Analysis of variance for 28-day split tensile strength (MPa) response surface quadratic model.

\begin{tabular}{|c|c|c|c|c|c|}
\hline Source & Sum of squares & Degrees of freedom & Mean square & $F$ value & $P$ value \\
\hline Model & 2.50 & 5 & 0.50 & 196.28 & $<0.0001$ \\
\hline A-HIPS (Vol \%) & 2.29 & 1 & 2.29 & 901.04 & $<0.0001$ \\
\hline$B-W / C$ ratio & 0.20 & 1 & 0.20 & 79.21 & $<0.0001$ \\
\hline$A B$ & 0.002500 & 1 & 0.002500 & 0.98 & 0.3547 \\
\hline$A^{2}$ & 0.00001388 & 1 & 0.00001388 & 0.005450 & 0.9432 \\
\hline$B^{2}$ & 0.0004496 & 1 & 0.0004496 & 0.18 & 0.6869 \\
\hline Residual & 0.018 & 7 & 0.002546 & & \\
\hline Lack of fit & 0.018 & 3 & 0.005941 & & \\
\hline Pure error & 0.000 & 4 & 0.000 & & \\
\hline Total & 2.52 & 12 & & & \\
\hline
\end{tabular}

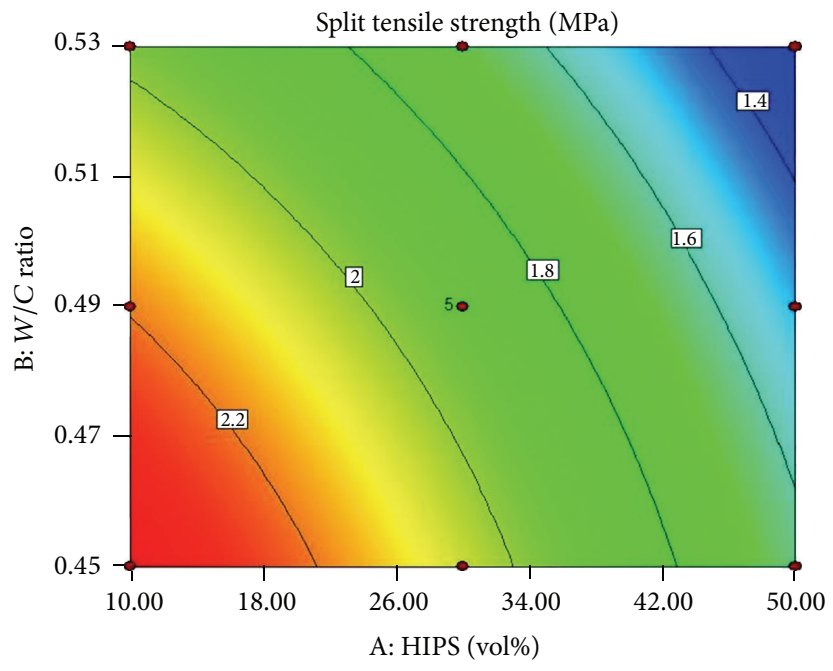

(a)

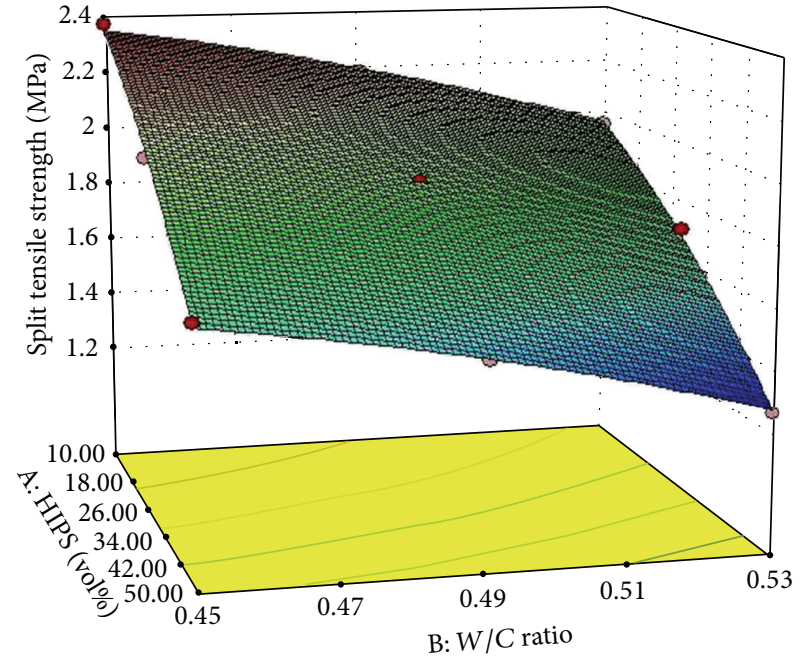

(b)

FIGURE 8: Contour plot and response surface of a 7-day split tensile strength.

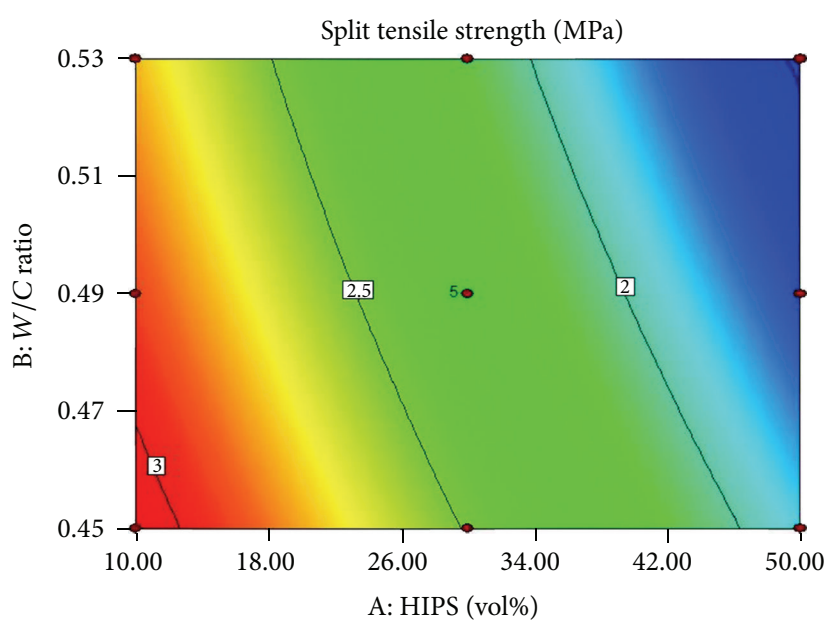

(a)

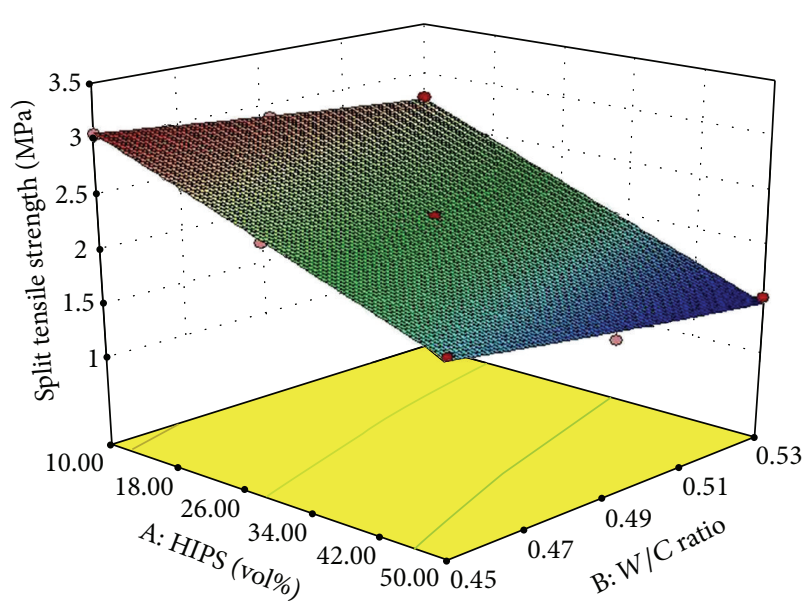

(b)

FIGURE 9: Contour plot and response surface of a 28-day split tensile strength. 


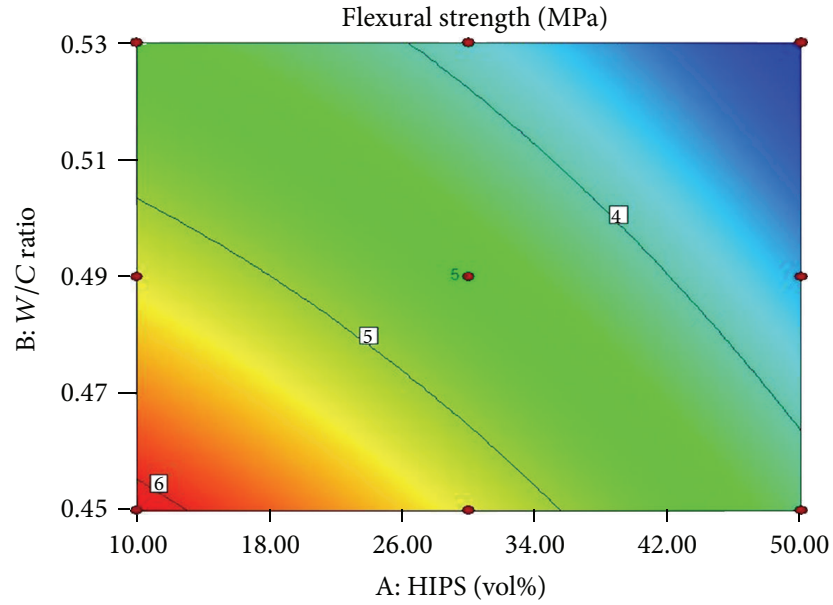

(a)

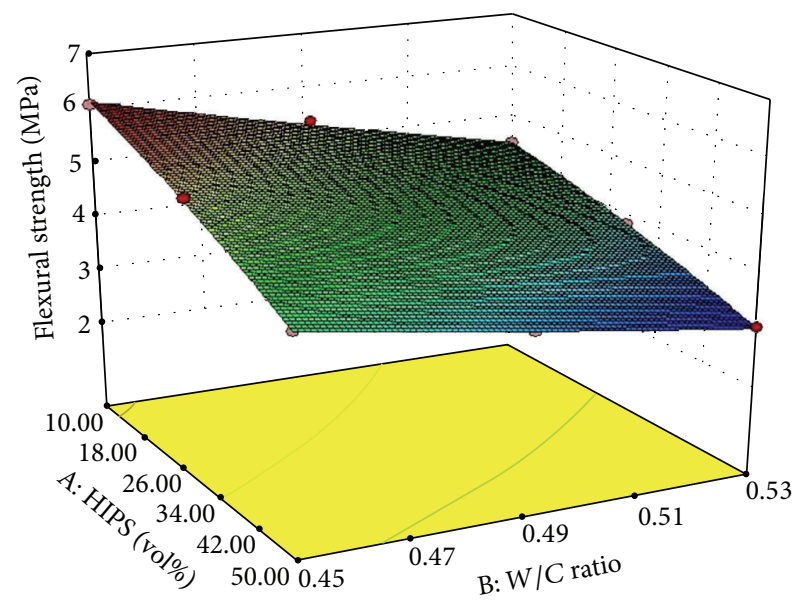

(b)

FIGURE 10: Contour plot and response surface of a 7-day flexural strength.

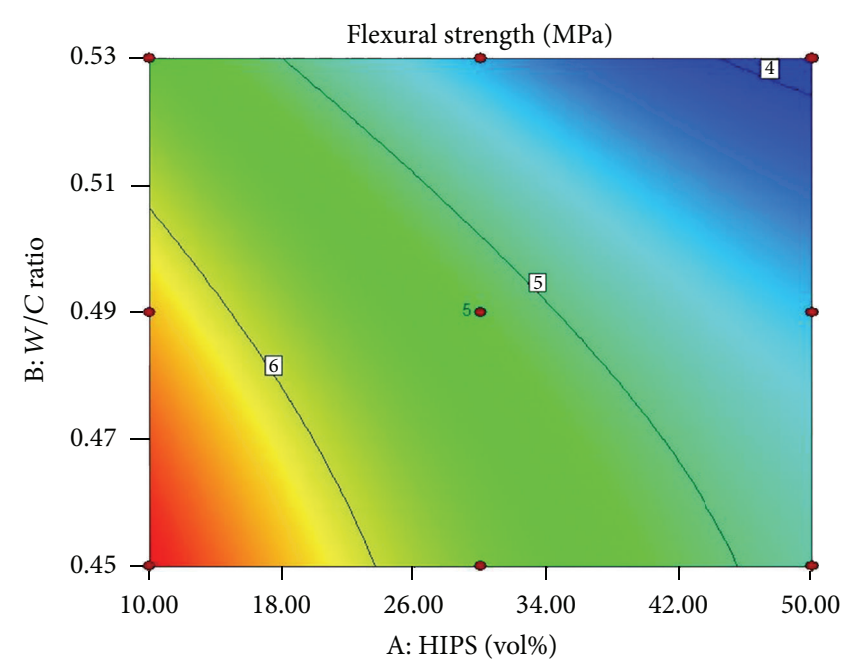

(a)

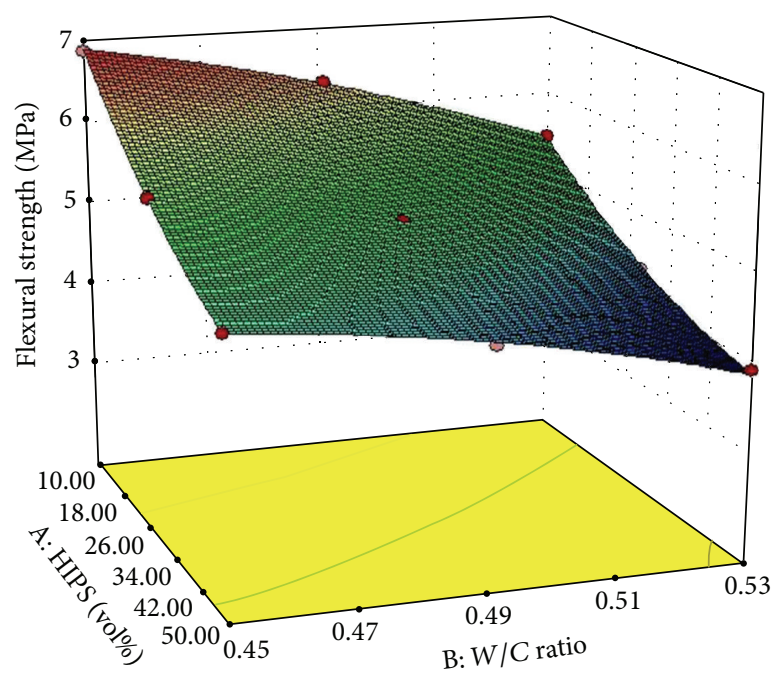

(b)

FIGURE 11: Contour plot and response surface of a 28-day flexural strength.

TABLE 14: Analysis of variance for 7-day flexural strength (MPa) response surface quadratic model.

\begin{tabular}{|c|c|c|c|c|c|}
\hline Source & Sum of squares & Degrees of freedom & Mean square & $F$ value & $P$ value \\
\hline Model & 7.18 & 5 & 1.44 & 938.32 & $<0.0001$ \\
\hline$A$-HIPS ( $\mathrm{Vol} \%)$ & 4.17 & 1 & 4.17 & 2723.15 & $<0.0001$ \\
\hline$B-\mathrm{W} / \mathrm{C}$ ratio & 2.93 & 1 & 2.93 & 1912.32 & $<0.0001$ \\
\hline$A B$ & 0.055 & 1 & 0.055 & 36.09 & 0.0005 \\
\hline$A^{2}$ & 0.030 & 1 & 0.030 & 19.84 & 0.0030 \\
\hline$B^{2}$ & 0.002514 & 1 & 0.002514 & 1.64 & 0.2407 \\
\hline Residual & 0.011 & 7 & 0.001530 & & \\
\hline Lack of fit & 0.011 & 3 & 0.003570 & & \\
\hline Pure error & 0.000 & 4 & 0.000 & & \\
\hline Total & 7.19 & 12 & & & \\
\hline
\end{tabular}




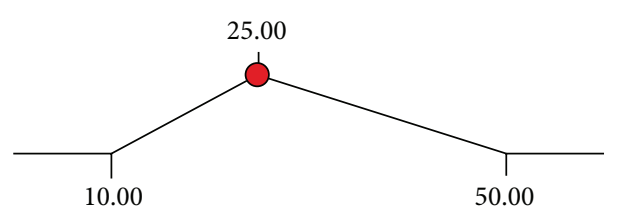

A: HIPS $($ vol $\%)=25.00$

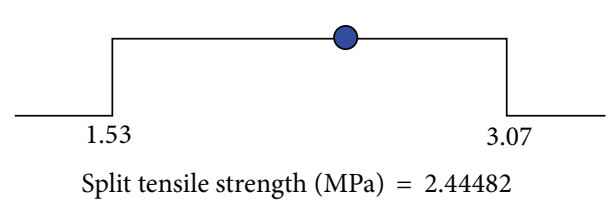

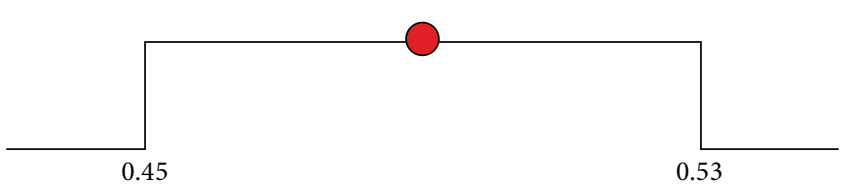

B: $W / C$ ratio $=0.49$

Desirability $=1.000$

FIgURE 12: Predicted response for 28-day split tensile strength.

TABLE 15: Analysis of variance for 28-day flexural strength (MPa) response surface quadratic model.

\begin{tabular}{|c|c|c|c|c|c|}
\hline Source & Sum of squares & Degrees of freedom & Mean square & $F$ value & $P$ value \\
\hline Model & 7.23 & 5 & 1.45 & 1305.46 & $<0.0001$ \\
\hline A-HIPS ( $\mathrm{Vol} \%)$ & 4.86 & 1 & 4.86 & 4385.45 & $<0.0001$ \\
\hline$B-W / C$ ratio & 2.17 & 1 & 2.17 & 1959.93 & $<0.0001$ \\
\hline$A B$ & 0.053 & 1 & 0.053 & 47.73 & 0.0002 \\
\hline$A^{2}$ & 0.14 & 1 & 0.14 & 125.20 & $<0.0001$ \\
\hline$B^{2}$ & 0.055 & 1 & 0.055 & 49.45 & 0.0002 \\
\hline Residual & 0.007757 & 7 & 0.001108 & & \\
\hline Lack of fit & 0.007757 & 3 & 0.002586 & & \\
\hline Pure error & 0.000 & 4 & 0.000 & & \\
\hline Total & 7.24 & 12 & & & \\
\hline
\end{tabular}

Table 14 shows that only the linear HIPS\%, $W / C$ ratio effects, and interaction effect $(P<0.0001, P<0.0001$, and $P=0.0005$, resp.) are statistically significant at the stipulated level of 5\%. Equation (9) is the final fitting equation:

7 day Flexural strength $(\mathrm{MPa})$

$$
=4.54-0.83 A-0.7 B-0.12 A B-0.1 A^{2}+0.03 B^{2} .
$$

Table 15 shows that the linear HIPS\%, linear $W / C$ ratio effects, interaction effect, and quadratic effects of HIPS and $W / C$ ratio are statistically significant at the stipulated level of $5 \%$. Equation (10) is the final fitting equation:

28 day Flexural strength $(\mathrm{MPa})$

$$
=5.19-0.90 A-0.6 B+0.12 A B+0.22 A^{2}-0.14 B^{2} \text {. }
$$

The effect of each variable on 7-day and 28-day flexural tensile strength is plotted as response and contour plot, as shown in Figures 10 and 11. Like the compressive strength, the spilt tensile strength and flexural strength decrease with the increase of HIPS for all $\mathrm{W} / \mathrm{C}$ ratios and for all curing periods.

In this study, all models are statically significant for chosen significant level of $5 \%$. The predicted $R$-squared, adjusted $R$-squared values and $F$ values for all responses are presented in Table 16.
4.3. Validation of Experiments. To validate the calculated statistical models for fresh and hardened properties of concrete with HIPS, experiments were conducted. For validation, the concrete mix with $25 \%$ HIPS volume percentage and 0.49 $W / C$ ratio were taken, responses were calculated using the models, and measurements were taken experimentally and are shown in Table 17. It can be seen from Table 16 that the experimental value closely agreed with the predicted value, which validates the calculated response surface models with desirability $=1$. A visual example for one response, that is, 28-day split tensile strength, using design expert is shown in Figure 12.

\section{Conclusion}

In this study, E-waste plastic (HIPS) was used as partial replacement of coarse aggregates in concrete. The experimental study has been conducted to assess the engineering properties of concrete with HIPS aggregate. The fresh and hardened properties of concrete with E-waste plastic (HIPS) such as slump, fresh density, dry density, 7-day compressive strength, 28-day compressive strength, 7-day split tensile strength, 28-day split tensile strength, 7-day flexural strength, and 28-day flexural strength were found experimentally. It was observed that the slump and fresh density have shown a significant decrease upon increasing the HIPS quantity. 
TABLE 16: Model statistics for all response variables.

\begin{tabular}{|c|c|c|c|c|c|}
\hline Responses & Predicted $R$-squared & Adjusted $R$-squared & $F$ value & Prob $>F$ & Model comment \\
\hline Slump & 0.8538 & 0.9667 & 70.65 & $<0.0001$ & Significant \\
\hline Fresh density & 0.9743 & 0.9857 & 129.25 & $<0.0001$ & Significant \\
\hline Dry density & 0.9720 & 0.9947 & 451.76 & $<0.0001$ & Significant \\
\hline 7-day compressive strength & 0.9232 & 0.9870 & 183.13 & $<0.0001$ & Significant \\
\hline 28-day compressive strength & 0.9083 & 0.9532 & 49.36 & $<0.0001$ & Significant \\
\hline 7-day split tensile strength & 0.9712 & 0.9950 & 474.17 & $<0.0001$ & Significant \\
\hline 28-day split tensile strength & 0.9435 & 0.9879 & 196.28 & $<0.0001$ & Significant \\
\hline 7-day flexural strength & 0.9870 & 0.9974 & 938.32 & $<0.0001$ & Significant \\
\hline 28-day flexural strength & 0.9899 & 0.9982 & 1305.46 & $<0.0001$ & Significant \\
\hline
\end{tabular}

TABLE 17: Validation of the response surface model (25\% HIPS, 0.49 $W / C$ ratio).

\begin{tabular}{lcc}
\hline Properties & Experiment & Predicted \\
\hline Slump $(\mathrm{mm})$ & 17.00 & 16.64 \\
Fresh density $\left(\mathrm{kg} / \mathrm{m}^{3}\right)$ & 2469.12 & 2472.61 \\
Dry density $\left(\mathrm{kg} / \mathrm{m}^{3}\right)$ & 2291.65 & 2285.02 \\
7-day compressive strength $(\mathrm{MPa})$ & 21.66 & 21.84 \\
28-day compressive strength $(\mathrm{MPa})$ & 31.62 & 30.26 \\
7-day split tensile strength $(\mathrm{MPa})$ & 1.97 & 1.98 \\
28-day split tensile strength $(\mathrm{MPa})$ & 2.35 & 2.44 \\
7-day flexural strength $(\mathrm{MPa})$ & 4.72 & 4.75 \\
28-day flexural strength $(\mathrm{MPa})$ & 5.52 & 5.43 \\
\hline
\end{tabular}

The concrete specimens were tested on 7 and 28 days. The compressive strength, splitting tensile strength, and flexural strength were found to be decreased by replacement of HIPS compared to control concrete. With the help of Design-Expert software, the measured experiment values were analyzed by face-centered composite surface design. Full quadratic model is employed and all models are found as significant. In all the models, linear effect of HIPS (Vol\%) was more significant when compared to other effects for a given stipulated level of 5\%. Finally, the predicted models were validated by experiments with $25 \%$ HIPS and $0.49 \mathrm{~W} / \mathrm{C}$ ratio. The results closely agreed with the predicted model, which implies that the predicted model is reliable. In future, these models can be used for framing guidelines for concrete mix design. Based on this investigation, it can be inferred that the concrete with HIPS up to $30 \%$ of replacement can be used for structural concrete. However, incorporation of E-waste plastic (HIPS) waste as an aggregate replacement in concrete has given scope to develop new construction materials valuable for both the construction and the electronic waste recycling industries.

\section{Conflict of Interests}

The authors declare that there is no conflict of interests regarding the publication of this paper.

\section{Acknowledgment}

The authors are thankful for Design-Expert version 9.0.3, Stat-Ease, Inc., Minneapolis, MN, USA.

\section{References}

[1] R. Widmer, H. Oswald-Krapf, D. Sinha-Khetriwal, M. Schnellmann, and H. Böni, "Global perspectives on e-waste," Environmental Impact Assessment Review, vol. 25, no. 5, pp. 436-458, 2005.

[2] P. Rekacewicz, "UNEP/GRID-Arendal. Who Gets the Trash? 'Basel Action Network: Vital Waste Graphics," 2014, http//www. grida.no/graphicslib/detail/who-gets-the-trash_10c0 and http:// maps.grida.no/go/graphic/who_gets_the_trash.

[3] 2014, http://toxicslink.org/, http://toxicslink.org/docs/06040_ repsumry.pdf.

[4] Central Pollution Control Board (CPCB), New Delhi, India, March 2013, http://cpcb.nic.in/e_Waste.php.

[5] E-Waste in India, 2011, http://rajyasabha.nic.in/rsnew/publication_electronic/E-Waste_in_india.pdf.

[6] P. Kiddee, R. Naidu, and M. H. Wong, "Electronic waste management approaches: an overview," Waste Management, vol. 33, no. 5, pp. 1237-1250, 2013.

[7] B. H. Robinson, "E-waste: an assessment of global production and environmental impacts," Science of the Total Environment, vol. 408, no. 2, pp. 183-191, 2009.

[8] Waste Electrical and Electronic Equipment, "The EU and India: sharing best practices," 2013, http://eeas.europa.eu/delegations/india/documents/eu_india/final_e_waste_book_en.pdf.

[9] K. S. Kumar and K. Baskar, "Recycling of E-plastic waste as a construction material in developing countries," Journal of Material Cycles and Waste Management, 2014.

[10] M. Yeheyis, K. Hewage, M. S. Alam, C. Eskicioglu, and R. Sadiq, "An overview of construction and demolition waste management in Canada: a lifecycle analysis approach to sustainability," Clean Technologies and Environmental Policy, vol. 15, no. 1, pp. 81-91, 2013.

[11] M. Shahria Alam, E. Slater, and A. H. M. Muntasir Billah, "Green concrete made with RCA and FRP scrap aggregate: fresh and hardened properties," Journal of Materials in Civil Engineering, vol. 25, no. 12, pp. 1783-1794, 2013.

[12] O. Çakır, "Experimental analysis of properties of recycled coarse aggregate (RCA) concrete with mineral additives," Construction and Building Materials, vol. 68, pp. 17-25, 2014. 
[13] G. Andreu and E. Miren, "Experimental analysis of properties of high performance recycled aggregate concrete," Construction and Building Materials, vol. 52, pp. 227-235, 2014.

[14] A. M. Ghaly and M. S. Gill, "Compression and deformation performance of concrete containing postconsumer plastics," Journal of Materials in Civil Engineering, vol. 16, no. 4, pp. 289296, 2004.

[15] Y. W. Choi, D. J. Moon, Y. J. Kim, and M. Lachemi, "Characteristics of mortar and concrete containing fine aggregate manufactured from recycled waste polyethylene terephthalate bottles," Construction and Building Materials, vol. 23, no. 8, pp. 2829-2835, 2009.

[16] Y.-W. Choi, D.-J. Moon, J.-S. Chung, and S.-K. Cho, "Effects of waste PET bottles aggregate on the properties of concrete," Cement and Concrete Research, vol. 35, no. 4, pp. 776-781, 2005.

[17] R. Siddique and T. R. Naik, "Properties of concrete containing scrap-tire rubber: an overview," Waste Management, vol. 24, no. 6, pp. 563-569, 2004.

[18] E. Ganjian, M. Khorami, and A. A. Maghsoudi, "Scrap-tyrerubber replacement for aggregate and filler in concrete," Construction and Building Materials, vol. 23, no. 5, pp. 1828-1836, 2009.

[19] A. Palos, N. A. D’Souza, C. T. Snively, and R. F. Reidy III, "Modification of cement mortar with recycled ABS," Cement and Concrete Research, vol. 31, no. 7, pp. 1003-1007, 2001.

[20] R. Wang, T. Zhang, and P. Wang, "Waste printed circuit boards nonmetallic powder as admixture in cement mortar," Materials and Structures, vol. 45, no. 10, pp. 1439-1445, 2012.

[21] R. Wang and C. Meyer, "Performance of cement mortar made with recycled high impact polystyrene," Cement and Concrete Composites, vol. 34, no. 9, pp. 975-981, 2012.

[22] R. Lakshmi and S. Nagan, "Utilization of waste E plastic particles in cementitious mixtures," Journal of Structural Engineering, vol. 38, no. 1, pp. 26-35, 2011.

[23] B. W. Colbert and Z. You, "Properties of modified asphalt binders blended with electronic waste powders," Journal of Materials in Civil Engineering, vol. 24, no. 10, pp. 1261-1267, 2012.

[24] C. H. Chen, R. Huang, J. K. Wu, and C. C. Yang, "Waste E-glass particles used in cementitious mixtures," Cement and Concrete Research, vol. 36, no. 3, pp. 449-456, 2006.

[25] Z. Hui and W. Sun, "Study of properties of mortar containing cathode ray tubes (CRT) glass as replacement for river sand fine aggregate," Construction and Building Materials, vol. 25, no. 10, pp. 4059-4064, 2011.

[26] T.-C. Ling and C.-S. Poon, "Utilization of recycled glass derived from cathode ray tube glass as fine aggregate in cement mortar," Journal of Hazardous Materials, vol. 192, no. 2, pp. 451-456, 2011.

[27] T.-C. Ling, C.-S. Poon, W.-S. Lam, T.-P. Chan, and K. K.-L. Fung, "Utilization of recycled cathode ray tubes glass in cement mortar for X-ray radiation-shielding applications," Journal of Hazardous Materials, vol. 199-200, pp. 321-327, 2012.

[28] T.-C. Ling and C.-S. Poon, "Use of recycled CRT funnel glass as fine aggregate in dry-mixed concrete paving blocks," Journal of Cleaner Production, vol. 68, pp. 209-215, 2014.

[29] D. Romero, J. James, R. Mora, and C. D. Hays, "Study on the mechanical and environmental properties of concrete containing cathode ray tube glass aggregate," Waste Management, vol. 33, no. 7, pp. 1659-1666, 2013.

[30] G. Sua-iam and N. Makul, "Use of limestone powder during incorporation of $\mathrm{Pb}$-containing cathode ray tube waste in selfcompacting concrete," Journal of Environmental Management, vol. 128, pp. 931-940, 2013.
[31] IS 12269-1987, Specification for 53 Grade Ordinary Portland Cement, Bureau of Indian Standards, New Delhi, India, 1987.

[32] IS 2386 (Part I-IV), "Methods of test for aggregates for concrete," Indian Standard, Bureau of Indian Standards, New Delhi, India, 1963.

[33] IS 10262-2009, Concrete Mix Proportioning-Guidelines, Bureau of Indian Standards, New Delhi, India, 2009.

[34] IS 456-2000, Plain and Reinforced Concrete-Code of Practice, Bureau of Indian Standards, New Delhi, India.

[35] "Indian standard code of practice - methods of test for strength of concrete," Tech. Rep. IS 516-1959, Bureau of Indian Standards, New Delhi, India, 2013.

[36] Bureau of Indian Standards, "Indian standard methods of sampling and analysis of concrete," IS 1199-1959, Bureau of Indian Standards, New Delhi, India, 1999.

[37] D. C. Montgomery, Design and Analysis of Experiments, John Wiley \& Sons, New York, NY, USA, 5th edition, 2001. 

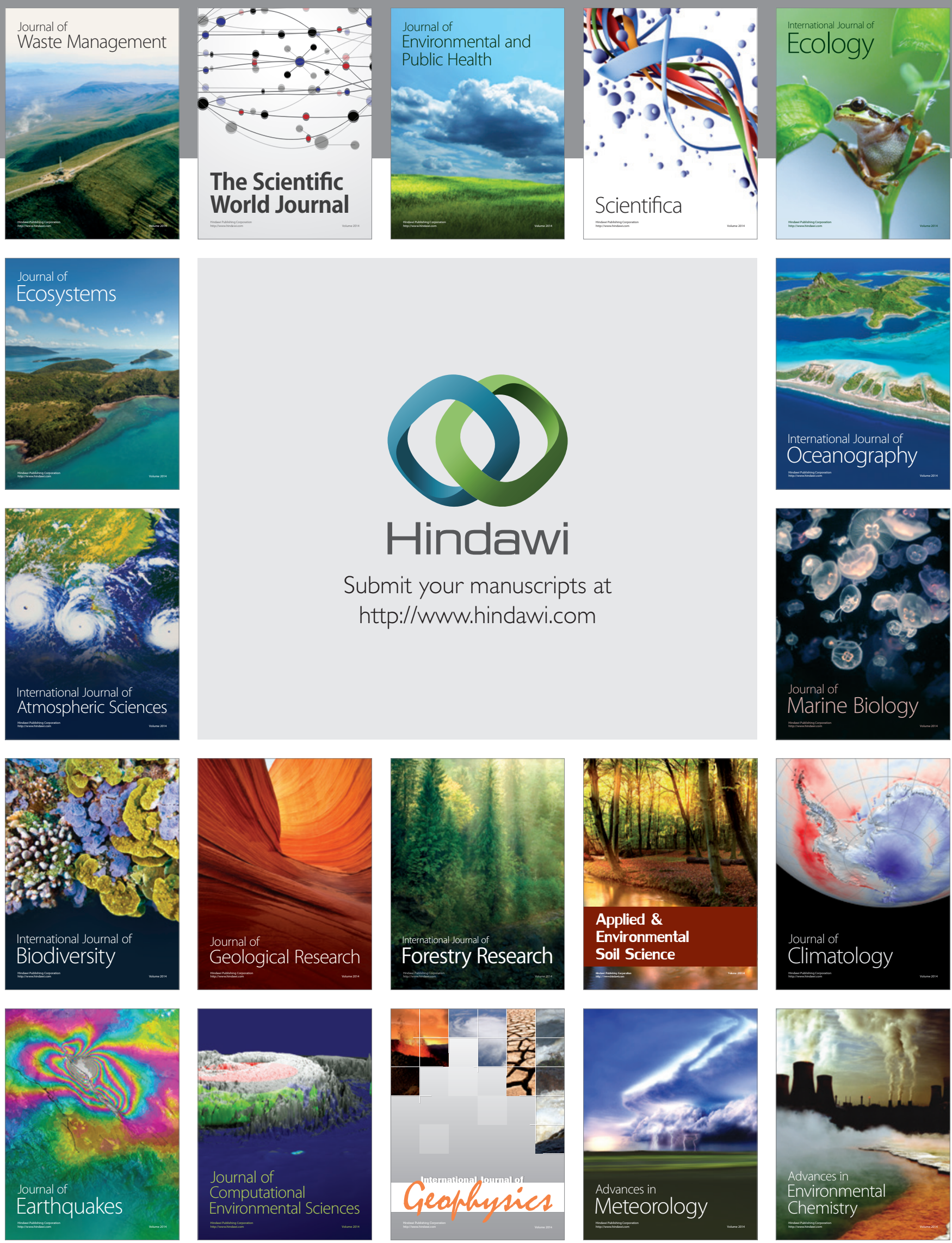